\title{
Immunisation of lambs with excretory secretory products of Oestrus ovis third instar larvae and subsequent experimental challenge
}

\author{
Stéphanie Frugère ${ }^{\mathrm{a}}$, Alfredo Cota LeON ${ }^{\mathrm{b}}$, Françoise PrÉvota ${ }^{\mathrm{a}}$, \\ Ramon CEPEDA PAlacios ${ }^{\mathrm{b}}$, Guillaume TABOURET ${ }^{\mathrm{a}}$, \\ Jean Paul Bergeaud ${ }^{\mathrm{a}}$, Christelle Duranton ${ }^{\mathrm{a}}$, Philippe DorChIES ${ }^{\mathrm{a}}$, \\ Philippe JACQUIET ${ }^{\mathrm{a} *}$
}

\author{
a UMR ENVT/INRA, Physiopathologie Infectieuse et Parasitaire des Ruminants, \\ École Nationale Vétérinaire de Toulouse, 23 chemin des Capelles, \\ 31076 Toulouse Cedex 03, France \\ ${ }^{\mathrm{b}}$ Universidad Autonoma de Baja California Sur, La Paz, BCS, Mexico
}

(Received 23 December 1999; accepted 5 June 2000)

\begin{abstract}
Excretory-secretory products (ESP) of myiasis producing agents are involved in nutrition and development of larvae and are often immunogens. This study was carried out in order to define the antigenicity, the immunogenicity of Oestrus ovis ESP and the role of sheep immune response to ESP. Twenty-four six to eight month old female lambs were randomly allocated into two groups. The first one was immunised twice, four weeks apart, with excretory-secretory products of Oestrus ovis third instar larvae (L3ESP) in complete then incomplete Freund adjuvant. The second one served as a control, and received two injections of PBS plus complete and incomplete Freund adjuvant. Fifteen and twenty-eight days after the second immunisation, animals of both groups were experimentally challenged with $O$. ovis first instar larvae. Twelve days after the second experimental challenge, the twenty-four lambs were necropsied. The total number of $O$. ovis larvae, their stages of development, weights and sizes were recorded per animal and compared between the two groups. Establishment rates were very similar in both groups: $39 \%$ and $35 \%$ in control and vaccinated groups respectively but the percentage of developing stages was higher in the control group (13\%) than in the vaccinated group $(6 \%)$. It was concluded that the L3ESP immunisation of sheep did not protect against larval establishment but provided an inhibitory effect on larval growth.
\end{abstract}

Oestrus ovis / excretory-secretory products / sheep / immunisation / experimental challenge

* Correspondence and reprints

Tel.: (33) 5611939 67; fax: (33) 5611939 44; e-mail: p.jacquiet@envt.fr 
Résumé - Immunisation d'agneaux avec des produits d'excrétion-sécrétion de larves de troisième stade d'Oestrus ovis et infestations expérimentales d'épreuve. Les produits d'excrétionsécrétion des larves de Diptères myiasigènes interviennent dans la nutrition et le développement de ces larves et sont très souvent immunogènes. Dans le cas de l'œstrose ovine, leurs propriétés antigéniques et immunogéniques n'ont pas encore été étudiées. De plus, le rôle exact de la réponse immune du mouton vis-à-vis des produits d'excrétion-sécrétion n'est pas connu et c'est ce qui a motivé ce travail. Vingt quatre agnelles âgées de six à huit mois ont été réparties de façon aléatoire en deux groupes de douze individus. Le premier groupe a reçu deux injections à quatre semaines d'intervalle d'un mélange de produits d'excrétion-sécrétion de larves de troisième stade d'Oestrus ovis et d'adjuvant complet puis incomplet de Freund. Le deuxième groupe a servi de témoin et a reçu seulement deux injections de PBS avec adjuvant complet puis incomplet de Freund. Quinze et trente jours après la deuxième immunisation, les animaux des deux groupes ont été infestés expérimentalement par des larves de premier stade d'Oestrus ovis. Douze jours après la seconde infestation expérimentale, tous les agneaux ont été abattus. Le nombre total de larves d'Oestrus ovis, leur stade de développement, leur taille ainsi que leur poids ont été comparés entre les deux groupes. Les taux d'installation des larves étaient très comparables dans les deux groupes (39\% chez les témoins et $35 \%$ chez les immunisés) mais le pourcentage de stades larvaires en développement était significativement plus important chez les témoins (13\%) que chez les immunisés $(6 \%)$. L'immunisation avec des produits d'excrétion-sécrétion de larves de troisième stade, bien que n'ayant pas protégé les agneaux de l'installation des larves, a conduit à une inhibition partielle du développement larvaire.

Oestrus ovis / produits d'excrétion-sécrétion / mouton / immunisation / infestation expérimentale

\section{INTRODUCTION}

Oestrus ovis larvae are obligatory parasites of nasal and sinusal cavities of sheep and goats [17]. Female flies seriously annoy sheep since they deposit first instar larvae (L1) on the nostrils leading to a loss of grazing time and condition of the sheep. L1 migrate to the ethmoid and molt to the second stage (L2) two to three weeks later. Intermediate stages, noted L1-L2, are easily distinguishable on a morphological basis. Then, L2 enter in the sinusal cavities where they molt to the third stage (L3) one to two weeks later. When the third instar larvae reach mature larval weight and size, they come back in the nasal cavities and are expelled by host sneezing. On the ground, they initiate pupation [7]. In the Oestridae family, adult flies have a reduced and nonfunctional oral apparatus [37]. Therefore, the weight of L3 at the end of the parasitic stage is of special importance: all the protein and energy reserves must be acquired by the larval stages. Fly viability is compromised for Oestrus ovis with mature larval weights below $0.28 \mathrm{~g}$ [8]. O. ovis infestations are associated with nasal and sinusal inflammations: nasal discharges and sneezing are frequent in heavily infested sheep [14]. In addition to these local effects, the parasites are sometimes responsible for lung abscesses and interstitial pneumonia [11]. The current methods of oestrosis control is chemotherapy [12, 13, 21, 23] because no alternative approach is yet available (no baits, no traps and no vaccines). Nevertheless, epidemiological studies have shown that under field conditions the intensities of infestations are less important in ewes than in lambs (Dorchies, unpublished results). Moreover, the survival of $O$. ovis larvae after artificial infestations was higher in immunodepressed animals than in control or immunostimulated animals [22] suggesting that immunological control of larval populations could occur in the field. Innocenti et al. [19] have shown that larval salivary gland proteins are major immunogens in infested sheep, indicating that excretorysecretory products (ESP) are likely to be involved in immunological relationships between the sheep host and the myiasis producing agent. In this study, it is postulated that immunisation of sheep with ESP might lead to the development of an immune 
response that interferes with the establishment and/or growth of Oestrus ovis larvae. Several trials of vaccination with ESP were carried out against common sheep parasites such as Fasciola hepatica [30, 34] and Haemonchus contortus [27] or myiasis producing species such as Lucilia cuprina in sheep [28, 29, 32, 33] or Hypoderma lineatum in cattle $[2,9,24,26]$ resulting in the reduced parasite burdens and/or fecundity or larval growth.

The aims of this study were (i) to demonstrate the antigenicity and the immunogenicity of excretory-secretory products of Oestrus ovis larvae and (ii) to compare the establishment and the growth of larvae in ESP vaccinated and control sheep.

\section{MATERIALS AND METHODS}

\subsection{Larval recovery and production of Excretory-Secretory Products (ESP)}

Heads of naturally infested sheep were collected in the slaughterhouse of Pezenas (South-East, France) and splitted to collect larvae from the septum, the turbinates, the ethmoid and sinusal cavities. Since third stage larvae produce large amounts of ES proteins, they were chosen to prepare ESP for sheep immunisation. L3 larvae were washed six times in PBS solution containing $100 \mathrm{U} \cdot \mathrm{mL}^{-1}$ penicillin and $100 \mu \mathrm{g} \cdot \mathrm{mL}^{-1}$ streptomycin and then incubated individually in $1 \mathrm{~mL}$ of incubation solution (PBS $\mathrm{pH} 7,0.15 \mathrm{M} \mathrm{NaCl}, 100 \mathrm{U} \cdot \mathrm{mL}^{-1}$ penicillin and $100 \mu \mathrm{g} \cdot \mathrm{mL}^{-1}$ streptomycin) for $24 \mathrm{~h}$ at $20{ }^{\circ} \mathrm{C}$ in the dark. Supernatants namely excretory-secretory products (ESP), were collected and centrifuged at $10000 \mathrm{~g}$ for $20 \mathrm{~min}$, filtered through a $0.8 \mu \mathrm{m}$ prefilter and a $0.2 \mu \mathrm{m}$ filter (Acrodisc, Nalgene, Ann Arbor, Michigan, USA). ESP were concentrated 10 times in concentrating tubes (Nalge, Polylabo, France) with a $4 \mathrm{kDa}$ molecular weight cut-off. Protein concen- trations were measured by Bicinchoninic (BCA) protein assay (Pierce, Rockford, Illinois, USA) with bovine serum albumin as the standard.

\subsection{Proteolytic activity}

The proteolytic effect of these ESP was tested using the degradation of Azo Dye Impregnated Collagen (Azocoll, SIGMA, USA) as described by Tamashiro et al. [31]. Briefly, $3 \mathrm{mg}$ of non-water soluble Azocoll were put in contact with either a positive control (collagenase type IA, $1 \mathrm{mg} \cdot \mathrm{mL}^{-1}$, SIGMA, Ref. C9891), or a negative control (PBS pH 7, $0.15 \mathrm{M} \mathrm{NaCl}$ ) or L3ESP $\left(0.5 \mathrm{mg} \cdot \mathrm{mL}^{-1}\right.$ diluted in PBS $)$ in a total volume of $0.5 \mathrm{~mL}$. After $1 \mathrm{~h}$ of incubation, optical densities were measured at $580 \mathrm{~nm}$ and the proteolytic activity (PA) calculated as follows:

$$
\mathrm{PA}=\frac{\mathrm{A}_{580} \mathrm{~L} 3 \mathrm{ESP}-\mathrm{A}_{580} \text { negative control }}{\mathrm{A}_{580} \text { positive control }-\mathrm{A}_{580} \text { negative control }} .
$$

\subsection{Antigenicity of ESP}

The antigenicity of L3ESP was checked by ELISA. Optical density values of five positive sheep sera (exposed under field conditions) and five negative sera (lambs four months old, born in the winter and never exposed to Oestrus ovis infestations) were compared using L3ESP and L2 crude extracts [35] as antigens. Briefly, L3ESP and L2 crude extracts were diluted in carbonate buffer ( $\mathrm{pH} 9.6$ ) at $2 \mu \mathrm{g} \cdot \mathrm{mL}^{-1}$, distributed in 96 well plates (Nunclon, Polylabo) and incubated for $1 \mathrm{~h}$ at $37^{\circ} \mathrm{C}$ then overnight at $4{ }^{\circ} \mathrm{C}$. The wells were washed three times with PBST (0.01 M phosphate, $0.15 \mathrm{M}$ sodium chloride, $\mathrm{pH} 7.2$ and $0.1 \%$ Tween 20). The antigen coated wells were then incubated for 30 min with a $10 \%$ skimmed milk solution at $37^{\circ} \mathrm{C}$ before blotting dry. Triplicate serum samples diluted in PBST $(1: 200)$ were incubated $60 \mathrm{~min}$ at $37^{\circ} \mathrm{C}$. The plates were washed three times 
with PBST before addition of horseradish peroxydase-conjugated donkey anti-sheep IgG (Sigma A3415) diluted (1:2 000) in carbonate buffer (60 min of incubation). Three final washes with PBST were carried out before addition and incubation at $37{ }^{\circ} \mathrm{C}$ of $100 \mu \mathrm{L}$ per well of the chromogen (2,2'Azino-bis (2-Ethylbenzthiazoline-6-Sul-

$$
\% \text { of antibodies }=\frac{\mathrm{OD}(\text { serum sample })-\mathrm{OD}(\text { negative control })}{\mathrm{OD}(\text { positive control })-\mathrm{OD}(\text { negative control })} \times 100 \text {. }
$$

\subsection{Animals}

Twenty-four Pelibuey female lambs, six to eight months old, maintained indoors from birth to their necropsy in order to avoid natural Oestrus ovis infestations, were randomly allocated into two groups (vaccinated and control). A clinical survey and blood samples were carried out weekly from Day 0 (first immunisation) to Day 70 (necropsies of the two groups).

\subsection{Immunisation of lambs}

In the vaccinated group, each animal received two IM injections in the neck, 4 weeks apart (D0 - D30), initially in Freund complete adjuvant and then in Freund incomplete adjuvant. The total amount of L3ESP injected into each sheep was $0.75 \mathrm{mg}$ of protein $(0.5 \mathrm{mg}$ in the first injection and $0.25 \mathrm{mg}$ in the second). The Freund complete and incomplete adjuvants were chosen since they elicit both strong humoral and cellular responses $[1,16]$. In the control group, the lambs received two injections of PBS with Freund complete and incomplete adjuvants.

\subsection{Experimental challenge}

Gravid Oestrus ovis flies were caught by hand in a commercial flock of 180 goats maintained during the heat of the day in a small pen. When the air temperature fonic Acid) Diammonium). The reaction was stopped after $1 \mathrm{~h}$ and the optical densities determined with a spectrophotometer by measuring the absorbance at $405 \mathrm{~nm}$. An antibody percentage is calculated for each serum sample by comparison with a positive reference serum (naturally exposed sheep) as follows: reached $20^{\circ} \mathrm{C}$, female $O$. ovis flies were very active and were looking for a suitable host for larviposition. Defensive reactions by the goats, the size and the characteristics of the fly were useful indicators for catchers to locate the flies. When the flies landed on the soil, the flanks, the ears or the necks of the animals, fly catch was possible.

First stage larvae were obtained by squeezing the abdomen of the gravid flies: the total amount of recovered larvae per fly varied from 80 to 250 . Larval viability was controlled in physiological buffer under a dissecting microscope: living L1 were pooled before their allocation into the inoculated batches. Experimental challenge occurred twice, on D45 (15 larvae per animal) and D58 (25 larvae per animal) after primary immunisation (namely 15 days and 28 days after the second immunisation). L1 were deposited in the nostrils of the animals with a Pasteur pipette. Their establishment was controlled by direct observation of their movements on the nostril mucosa.

\subsection{Control of immunisation efficiency}

The kinetics of Oestrus ovis L3ESP specific IgG antibodies was monitored weekly by ELISA (see procedure above) from D0 to D70 (date of postmortem examinations). After splitting of the heads, larvae were collected from the septum, the turbinates, the ethmoid and the sinusal cavities, were counted and their stages (L1, molt L1 to L2, L2 and L3) were identified. Their weights 
and their sizes were individually recorded using a $0.01 \mathrm{mg}$ precision balance and a micrometer under a dissecting microscope respectively.

\subsection{Statistical analysis}

The results were statistically analysed using Stat-Itcf and Simstat Softwares. L1 weights and lengths were analysed by a one way analysis of variance (ANOVA, StatItcf) and L2 and L3 weights by the MannWhitney two sample test (Simstat) due to the low number of L2 and L3 recovered. Comparisons of L1 and developing stages (L1-L2, L2 and L3) frequencies between the vaccinated and the control groups were done with the Chi-square test (Stat-Itcf).

\section{RESULTS}

\subsection{Proteolytic activity and antigenicity of L3ESP}

L3ESP showed a high proteolytic effect. The proteasic activity (PA) of L3ESP was
$78 \%$ of the PA of the positive control (collagenase type IA). Moreover, L3ESP showed a high antigenicity compared to the reference antigen (L2 crude extract). In ELISA test using identical protein concentrations, the optical densities were similar in the negative control sera $(0.023 \pm 0.008$ and $0.022 \pm 0.013$ with L3ESP and L 2 crude extract respectively) whereas the optical densities of positive sera were two to three times higher with the L3ESP antigen $(0.24 \pm 0.12)$ than with the L2 crude extract antigen (0.094 \pm 0.04$)$.

\subsection{Immunisation, experimental challenge and postmortem examinations}

ELISA data (Fig. 1) showed that IgG antibody titers began to increase after the first immunisation in the vaccinated group with L3ESP and reached a plateau two weeks after the second one. One lamb from the vaccinated group showed a low level of IgG before the first immunisation and was removed from this group. On the contrary,

Specific IgG antibody titers

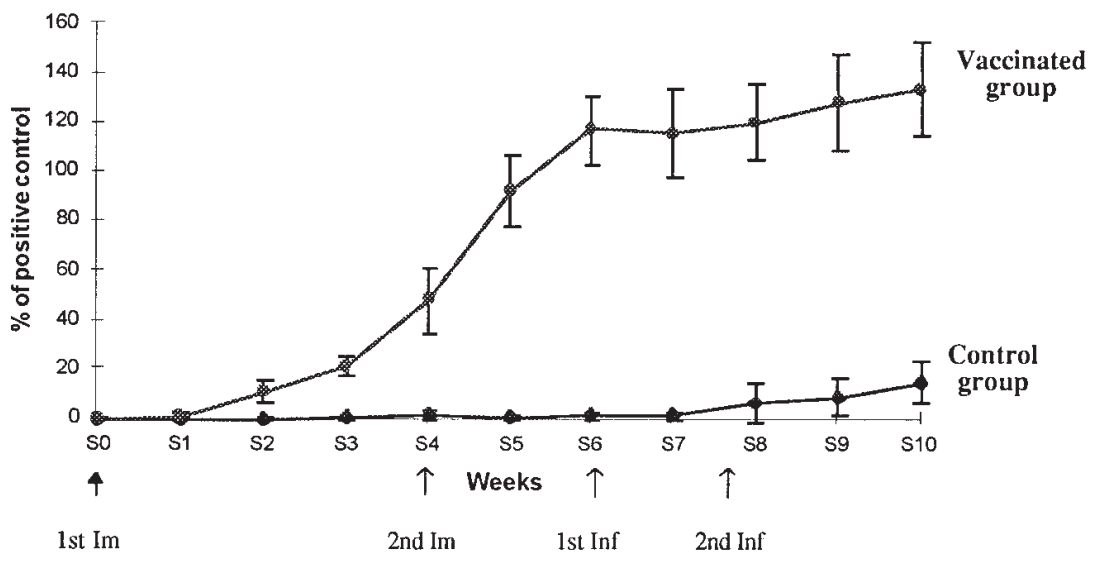

Figure 1. Oestrus ovis specific IgG antibody titers in control and vaccinated groups tested by ELISA. 1st Im: first immunisation (500 $\mu \mathrm{g}$ of L3ESP + FCA $) ; 2$ nd Im: second immunisation $(250 \mu \mathrm{g}$ of L3ESP + FIA); 1st Inf: first experimental challenge (15 L1); 2nd Inf: second experimental challenge (25 L1). 
Table I. Postmortem examinations of control and vaccinated sheep: number and stage of recovered larvae after challenge (15 and 25 larvae per animal, 15 and 28 days after the 2 nd immunisation).

\begin{tabular}{lcccccc}
\hline Groups & $\begin{array}{c}\text { No of } \\
\text { animals }\end{array}$ & No of L1 & No of L1-L2 & No of L2 & No of L3 & Total \\
\hline Control & 1 & 14 & 0 & 0 & 0 & \\
& 4 & 13 & 0 & 1 & 0 & 14 \\
& 7 & 11 & 1 & 7 & 1 & 20 \\
& 9 & 13 & 0 & 0 & 0 & 13 \\
& 10 & 12 & 1 & 0 & 0 & 13 \\
& 12 & 16 & 0 & 0 & 1 & 17 \\
& 13 & 7 & 0 & 0 & 0 & 7 \\
Total control group & 19 & 20 & 0 & 3 & 0 & 23 \\
\hline Vaccinated & 175 & 8 & 0 & 3 & 0 & 11 \\
& 197 & 22 & 0 & 0 & 0 & 22 \\
& 199 & 13 & 0 & 2 & 0 & 15 \\
& $\mathbf{1 2}$ & 15 & 2 & 3 & 0 & 20 \\
& 2 & $13.7 \pm \mathbf{4 . 1}$ & $\mathbf{0 . 3 3} \pm \mathbf{0 . 6}$ & $\mathbf{1 . 5 8} \pm \mathbf{2}$ & $\mathbf{0 . 1 6} \pm \mathbf{0 . 3 7}$ & $\mathbf{1 5 . 7 5} \pm \mathbf{4 . 6}$ \\
\hline & 3 & 17 & 1 & 2 & 1 & 22 \\
& 5 & 10 & 0 & 0 & 0 & 17 \\
& 6 & 8 & 0 & 0 & 0 & 10 \\
& 8 & 11 & 0 & 0 & 0 & 8 \\
& 11 & 21 & 0 & 2 & 0 & 11 \\
& 14 & 18 & 0 & 2 & 0 & 23 \\
& 15 & 7 & 0 & 0 & 0 & 20 \\
& 16 & 20 & 0 & 1 & 0 & 21 \\
& 18 & 10 & 0 & 0 & 0 & 10 \\
& 20 & 6 & 0 & 0 & 0 & 6 \\
& $\mathbf{1 1}$ & $\mathbf{1 3 . 2 7} \pm \mathbf{5 . 3}$ & $\mathbf{0 . 1} \pm \mathbf{0 . 3}$ & $\mathbf{0 . 6 3} \pm \mathbf{0 . 9}$ & $\mathbf{0 . 1} \pm \mathbf{0 . 3}$ & $\mathbf{1 4} \pm \mathbf{6 . 2}$ \\
& & & & & &
\end{tabular}

IgG antibody titers remained very low in the control group and began to increase slightly only after the first experimental challenge. Clinical signs of oestrosis (nasal discharge and sneezing) appeared in an equal manner in the two groups from 11 days after the first experimental challenge until the end of the experiment.

The establishment rates of larvae (Tab. I) were very similar in the two groups $(39 \%$ and $35 \%$ in the control and the vaccinated groups respectively). However, the control group showed a higher frequency of developing stages (L1-L2, L2 and L3) than the vaccinated group $(13 \%$ versus $6 \%$ of the total recovered larvae, Chi-square $=5.43$, $P=0.019)$. Length $(\mathrm{mm})$ and weight $(\mu \mathrm{g})$ of recovered L1 were higher in the control group $(2.09 \pm 0.6 \mathrm{~mm}$ and $420 \pm 569 \mu \mathrm{g})$ than in the vaccinated group $(1.96 \pm 0.5 \mathrm{~mm}$ and $392 \pm 417 \mu \mathrm{g}$ ) but the difference was only significant for the length data $(P=0.055)$ due to an important individual variability in weight measures. Weights of L1-L2, L2 and L3 were not significantly different between the two groups.

No correlation between the IgG antibody titers and the number of recovered larvae was observed in the vaccinated group.

\section{DISCUSSION}

L3ESP of Oestrus ovis exhibited a strong proteolytic effect when compared to a bacterial collagenase. This evokes hypodermins, 
enzymes secreted by Hypoderma lineatum [4] and Chymotrypsin-like enzymes secreted by the gut of Lucilia cuprina [6]. These enzymes are likely involved in the extracorporeal digestion of protein fluids from the host. Moreover, L3ESP have similar proteolytic effects on other sheep protein constituents such as albumin and mucine (Tabouret, unpublished results). L3ESP are very antigenic: the optical densities observed with an L3ESP antigen are two to three times higher than those obtained with an L2 crude extract antigen. These findings suggest that specific antibodies could be induced and could interfere with the extracorporeal digestion and consequently with larval growth.

Experimental challenges were performed with first instar larvae coming directly from the uterine tract of female flies. This is the first time that this type of artificial infestation has been carried out on such a quantity of experimental lambs (Cobett and Mitchell in 1941 [10] and Babcock in 1953 [3] made experimental infestations in a few animals using the same technique). Previous experimental infestations performed with L1 recovered from slaughtered sheep [36], resulted in single infestation and repeated infection establishment rates of 25-40\% and $10-15 \%$, respectively. In the present case, the establishment rates in the control group were high (near 40\%) even in a double infestation situation suggesting that a high proportion of L1 contained in the female fly uterus was able to settle into a suitable host.

Two outcomes of this preliminary study of sheep immunisation could be drawn: (i) the lack of control of larval establishment despite an important IgG response and (ii) the slight inhibition or delay of larval development. Since necropsies occurred quickly after the immunisations and experimental challenges, the duration of this effect on larval development was unknown. Some ESP candidate vaccines have shown similar effects (no interference with parasite establishment but interference with fecundity or parasite development): cathepsins L-like of
Fasciola hepatica delivered twice in Freund adjuvant did not significantly reduce worm burdens compared with the non-vaccinated animals; however, there was a $70 \%$ reduction in the output of eggs in the vaccinated animals [30, 34]. A very weak naturally acquired resistance to the Lucilia cuprina blowfly strike is developed in sheep after repeated infestations of larvae [32]. A strong humoral response is induced by excretory-secretory products of the larvae especially the salivary glands and midgut extracts [29] and can significantly inhibit larval growth in vitro [28]. However, this inhibitory effect was not observed in in vivo tests, even with purified serine proteases from ESP [33]. In contrast, two low molecular weight excretory-secretory proteins of adult Haemonchus contortus worms induce a significant reduction of both worm burden and faecal egg counts [27]. In cattle, the development of a partial resistance to Hypoderma lineatum is acquired after successive natural infestations [26] but attempts to immunise calves with cattle grubs digestive enzymes, the hypodermins, did not lead to a protection of these animals [2, 24].

What could be the possible reasons for the relative failure of Oestrus ovis L3ESP immunisation? First of all, for practical reasons, we used L3ESP for sheep immunisation instead of L1ESP. Nevertheless, preliminary results showed that proteolytic activity and SDS-PAGE analysis of L1ESP and L3ESP are very similar (Tabouret, unpublished results). Excretory-secretory products are a mixture of several different proteins and immunisation of host with such material elicits a lot of different immune responses. Thus, immunisation with a purified proteolytic fraction of $O$. ovis ESP could result in a more targeted and efficient immune response.

Since the development of Oestrus ovis larvae occurs in contact with the nasal and the sinusal mucosae, it could be judicious, in the near future, to choose intranasal route of immunisation and a specific adjuvant of mucosal immunity. Bowles et al. [5] 
demonstrated that intranasal immunisation of sheep with a second stage excretorysecretory antigen preparation of Lucilia cuprina results in a significant reduction in larval numbers after an experimental challenge whereas intradermal immunisation does not protect the animals. Nasal immunisations are known to be very efficient for induction of systemic and mucosal antibodies [18] via the solicitation of the nasopharyngeal lymphoid tissue [20]. The role of adjuvants has been underlined by several workers. A Lucilia cuprina first instar larvae antigen mixture in a Dextran Sulphate/FIA combination produces a protective immune response similar to that obtained with FCA whereas the same antigen mixture combined with Quil A, Alhydrogel, or Dextran Sulfate alone does not protect the animals [16]. In the same vein, two veterinary acceptable adjuvants, alhydrogel and amphigel, alone or in combination, as adjuvants of Hypodermin A do not induce levels of antibodies, delayed-type skin reaction and cellular infiltration in cattle that are comparable to those of an FCA formulated Hypodermin A vaccine [25]. Another approach could be the use of hidden antigens of the larval gut: immunisation of sheep with peritrophin membrane antigens of Lucilia cuprina reduces larval growth by $30 \%$ both in vitro and in vivo [15].

Nevertheless, these preliminary results obtained with Oestrus ovis L3ESP immunisation are encouraging and require further investigations using natural (purified proteolytic enzymes) or hidden (gut constituents) antigens in intranasal routes of immunisations in combination with commercially acceptable adjuvants.

\section{ACKNOWLEDGEMENTS}

We are very grateful to Aida Mendoza Mendez and Alberto Monroy Cesena for technical help and to Hervé Hoste for helpful discussions.

\section{REFERENCES}

[1] Audibert F.M., Lise L.D., Adjuvants: current status, clinical perspectives and future prospects, Immunol. Today 14 (1993) 281-284.

[2] Baron R.W., Colwell D.D., Enhanced resistance to cattle grub infestation (Hypoderma lineatum de Vill.) in calves immunized with purified hypodermin A, B and C plus monophosphoryl lipid A (MPL), Vet. Parasitol. 38 (1991) 185-197.

[3] Babcock O.G., Notes on the biology of Oestrus ovis L. Bull. E-871, USDA-ARS, Texas Agricult. Station, 1953.

[4] Boulard C., Garrone R., Characterization of a collagenolytic enzyme from larvae of Hypoderma lineatum (Insecta: Diptera, Oestriform), Comp. Biochem. Physiol. B 59 (1978) 251-255.

[5] Bowles V.M., Carnegie P.R., Sandeman R.M., Immunisation of sheep against infection with larvae of the blowfly Lucilia cuprina, Int. J. Parasitol. 17 (1987) 753-758.

[6] Casu R.E., Eisemann C.H., Vuocolo T., Tellam R.L., The major excretory-secretory protease from Lucilia cuprina larvae is also a gut digestive protease, Int. J. Parasitol. 26 (1996) 623-628.

[7] Cepeda-Palacios R., Scholl P.J., Intra-puparial development in Oestrus ovis (Diptera: Oestridae), J. Med. Entomol. 37 (2000) 239-245.

[8] Cepeda-Palacios R., Frugère S., Dorchies P., Expected effects of reducing Oestrus ovis L. mature larval weight on adult populations, Vet. Parasitol. 90 (2000) 239-246.

[9] Chabaudie N., Villejoubert C., Boulard C., The response of cattle vaccinated with hypodermin A to a natural infestation of Hypoderma bovis and Hypoderma lineatum, Int. J. Parasitol. 21 (1991) 859-862.

[10] Cobbett N.G., Mitchell W.C., Further observations on the life cycle and incidence of the sheep bot, Oestrus ovis, in New Mexico and Texas, Am. J. Vet. Res. 2 (1941) 358-366.

[11] Dorchies P., Yilma J.M., Savey J., Prevalence of lung abscesses and interstitial pneumonia in ovine oestrosis, Vet. Rec. 133 (1993) 325.

[12] Dorchies P., Cardinaud B., Fournier R., Efficacy of moxidectin as a $1 \%$ injectable solution and a $0.1 \%$ oral drench against nasal bots, pulmonary and gastrointestinal nematodes in sheep, Vet. Parasitol. 65 (1996) 163-168.

[13] Dorchies P., Alzieu J.P., Cadiergues MC., Comparative curative and preventive efficacies of ivermectin and closantel on Oestrus ovis (Linné $1758)$ in naturally infected sheep, Vet. Parasitol. 72 (1997) 179-184.

[14] Dorchies P., Duranton C., Jacquiet P., Pathophysiology of Oestrus ovis infection in sheep and goats: a review, Vet. Rec. 142 (1998) 487-489.

[15] East I.J., Eisemann C.H., Vaccination against Lucilia cuprina: the causative agent of sheep 
blowfly strike, Immunol. Cell Biol. 71 (1993) 453-462.

[16] East I.J., Eisemann C.H., Vuocolo T., Pearson R.D., Donaldson R.A., Cadogan L.C., Vaccines against blowfly strike: the effect of adjuvant type on vaccine effectiveness, Int. J. Parasitol. 22 (1992) 309-314

[17] Hall M., Wall R., Myiasis of humans and domestic animals, Adv. Parasitol. 35 (1995) 257-334.

[18] Hvalbye B.K.R., Aaberge I.S., Lovik M., Haneberg B., Intranasal immunisation with heatinactivated Streptococcus pneumoniae protects mice against systemic pneumococcal infection, Infect. Immun. 676 (1999) 4320-4325.

[19] Innocenti L., Masetti M., Macchioni G., Giorgi F., Larval salivary gland proteins of the sheep nasal bot fly, (Oestrus ovis L.), are major immunogens in infested sheep, Vet. Parasitol. 60 (1995) 273282.

[20] Kuper C.F., Koornstra P.J., Hameleers D.M.H., Biewenga J., Spit B.J., Duijvestijn A.M., van Breda Vriesman P.J.C., Sminia T., The role of nasopharyngeal lymphoid tissue, Immunol. Today 13 (1992) 219-224.

[21] Lucientes J., Castillo J.A., Ferrer L.M., Peribanez M.A., Ferrer-Dufol M., Gracia-Salinas M., Efficacy of orally administrated ivermectin against larval stages of Oestrus ovis in sheep, Vet. Parasitol. 75 (1998) 255-259.

[22] Marchenko V.A., Marchenko V.P., Survival of the larvae of the sheep botfly Oestrus ovis L. depending on the function of the immune system of the host'body, Parazitologiia 23 (1989) 129133.

[23] Puccini V., Giangaspero A., Fasanella A., Efficacy of moxidectin against Oestrus ovis larvae in naturally infested sheep, Vet. Rec. 135 (1994) 600-601.

[24] Pruett J.H., Immunological control of arthropod ectoparasites - a review, Int. J. Parasitol. 29 (1999) 25-32.

[25] Pruett J.H., Stromberg P., Effects of adjuvants on bovine humoral and cellular responses to hypodermin A, Vet. Parasitol. 58 (1995) 143-153.

[26] Pruett J.H., Kunz S.E., Development of resistance to Hypoderma lineatum (Diptera: Oestridae) within a cattle herd, J. Med. Entomol. 33 (1996) 49-52.
[27] Schallig H.D., van Leeuwen M., Cornelissen A., Protective immunity induced by vaccination with two Haemonchus contortus excretory secretory proteins in sheep, Parasite Immunol. 19 (1997) 447-453.

[28] Seaton D.S., O'Meara T.J., Chandler R.A., Sandeman R.M., The sheep antibody response to repeated infection with Lucilia cuprina, Int. J. Parasitol. 22 (1992) 1169-1174.

[29] Skelly P.J., Howells A.J., The humoral immune response of sheep to antigens from larvae of the sheep blowfly (Lucilia cuprina), Int. J. Parasitol. 17 (1987) 1081-1087.

[30] Spithill T.W., Dalton J.P., Progress in development of liver fluke vaccines, Parasitol. Today 14 (1998) 224-228.

[31] Tamashiro W.K., Rao M., Scott A.L., Proteolytic cleavage of IgG and other protein substrates by Dirofilaria immitis microfilarial enzymes, J. Parasitol. 73 (1987) 149-154.

[32] Tellam R.L., Bowles V.M., Control of blowfly strike in sheep: current strategies and future prospects, Int. J. Parasitol. 27 (1997) 261-273.

[33] Tellam R.L., Eisemann C.H., Pearson R.D., Vaccination of sheep with purified serine proteases from the secretory and excretory material of Lucilia cuprina larvae, Int. J. Parasitol. 24 (1994) 757-764.

[34] Wijffels G.L., Salvatore L., Dosen M., Waddington J., Wilson L., Thompson C., Campbell N., Sexton J., Wicker J., Bowen F., Friedel T., Spithill T.W., Vaccination of sheep with purified cysteine proteinases of Fasciola hepatica decreases worm fecundity, Exp. Parasitol. 78 (1994) 132-148.

[35] Yilma J.M., Contribution à l'étude de l'épidémiologie, du diagnostic immunologique et de la physiopathologie de l'oestrose ovine (Oestrus ovis Linné 1758), Thèse de l'Institut National Polytechnique de Toulouse, 1992, 218 p.

[36] Yilma J.M., Dorchies P., Essais d'infestations expérimentales de l'agneau par des larves 1 d'Oestrus ovis, Bull. Soc. Franç. Parasitol. 43 (1993) 43-47.

[37] Zumpt F., Myiasis in man and animals in the old world, Butterworth Ed., London, 1965. 